\title{
Political and economic factors in the evolution of North Korea's maritime connections
}

\author{
César Ducruet ${ }^{*}$, Stanislas Roussin ${ }^{* *}$ and Jin-Cheol Jo ${ }^{* * *}$
}

\begin{abstract}
This paper is an empirical attempt to verify the interplay between political change, fleet nationality, and the evolution of shipping networks. North Korea offers a good example of a socialist maritime country that has experienced much contrasting geopolitical contexts since 1990. A database of vessel movements between North Korean ports and other ports is analyzed. Main results show differences between North Korean and foreign fleets in terms of traffic (vessel size, age, berthing time) and geographical coverage. South Korean ports tend to play a new role in the reorganization of North Korean-related flows in Northeast Asia.
\end{abstract}

Keywords: The Democratic People's Republic of Korea (DPRK), Maritime network, North Korea, Northeast Asia, Port system

\section{Introduction: maritime networks and geopolitical change}

Contemporary globalization and regionalization processes are often said to diminish the importance of nation-states and nationality in economic and spatial change. Throughout port and maritime studies, the evolution of port and maritime systems is usually studied through the economic rationale of firms. This is justified by the unprecedented importance of shipping lines,

Submission Date: 20/06/2008～～Revision Date: 18/04/2009

Acceptance Date: 18/04/2009

"Corresponding Author, French National Centre for Scientific Research (CNRS) University of Paris I Sorbonne, UMR 8504 Géographie-cités, Equipe P.A.R.I.S., 13 rue du Four, F-75006 Paris, France. Tel.: +33(0)140-464-007, Fax: +33(0)140-464-009, Email: ducruet@parisgeo.cnrs.fr

* SERIC Corée \#1302, Byucksan-digital valley V,60-73, Gasan-dong, Geumcheon-Gu, Seoul 153-801, Republic of Korea. Tel.: +82(0)2-2082-5613, Fax: +82(0)2-2082-5616, Email: roussin@ seric-coree.com

**** Korea Research Institute for Human Settlements (KRIHS), 1591-6 Gwanyang-dong, Dongan-gu, Anyang-si, Gyeonggido 431-712 Republic of Korea. Tel.: +82(0)31-380-0164, Fax: +82(0)31-380-0482, Email: jincjo@krihs.re.kr 
freight forwarders, and terminal operators in the transformation of transport chains (Ducruet and Van Der Horst 2009). Technological and managerial revolutions in the maritime world - and in transport systems in general - have weakened the role of ports and countries in the decision process about where the cargo must be shipped to reach a given destination (Slack 1993). Therefore, scholars have adapted to these large-scale changes by producing extensive works about the role of the so-called global players in port development, port competition, and port selection. Notably about East Asia, recent research on port growth and maritime systems has primarily focused on economic factors and market forces (Comtois 1994 and 1999; Robinson 1998; Rimmer 2004; Rimmer and Comtois 2005; Yap et al. 2006; Parola et al. 2006; Notteboom 2006). In one of his major contributions entitled The Sea and the Geostrategy of Nations, the French geographer André Vigarié (1995) expresses an alternative viewpoint:

"A commercial operation has always a certain political significance. Commodities or economic activities for the exchange of goods are rarely neutral. They carry the print of the society where they comes from, which possesses its own rules of external relations, its forms and its domains of production; they vehicle their lingual and cultural characteristics; they are witnesses of a form of civilization; they are the expression of interests that are not totally shared by all partners; they express a policy, which means a dynamic of insertion in the outside world: liberal, socialist... Trading is thus expressing certain behavior; and the sea, with the ports, constitutes one of the most important vectors for transmitting this cultural, economical and political background." (pp. 5-6, translated by the authors).

Most literature on geopolitics and shipping is often related with naval warfare, geopolitical control of seas, islands, straits and canals (Papon 1996), implementation of coastal shipping in transport policies (Rowlinson and Wixey 2002; Kunth and Thorez 2005), and security issues in the transport chain (Carluer, Alix and Joly 2008). Another important aspect is brought by historical studies of port development under colonial rule, notably in Asia, with special reference to diverging interests among empires, merchants, and local elites (Basu 1985; Broeze 1989). Contrastingly, the economic literature has largely ignored that ports and transport firms are also influenced in their evolution by geopolitical and political factors. There seem to be a contradiction in port geography between the reluctance to establish general models due to the claimed importance of local political factors, and the limited study of such factors given the clear majority of economic-oriented studies in the literature (Ducruet, Notteboom and De Langen 2009). Therefore, our research focus opts for an intermediate position between traditional geopolitics and current economic approaches. Two main sets of recent research foci can be distinguished in the economic literature: the territorial embededdness of port development (local) and the political dimension of port selection by firms (global).

The first research focus is based on the idea that ports are institutions embedded in a territorial structure where power relations are fundamental. Such views aim at balancing the dominant approach on competitive performance, notably in the case of port competition between Los Angeles and Long Beach that are subject to resilient historical, path-dependent administrative and political influences (Jacobs 2007). Other authors have insisted on the interplay between political culture and port performance in their comparison of Busan, Rotterdam, and Piraeus (Ng and Pallis 2007). Accordingly, global forces encounter contrasted local forces such as urban growth, planning 
policies, and cross-border integration in the case of Singapore and Hong Kong hub port cities (Lee and Ducruet 2009). Following the collapse of the USSR and the socialist block, ports located in the new republics - Black Sea (e.g. Ukraine, Georgia), Baltic Sea (e.g. Estonia, Latvia), Adriatic Sea (e.g. Slovenia) - had to redefine their functions and diversify their traffic (Thorez 1998), while the Baltic ports remained for a large part of their traffic dependent on resilient Russian transit trade (Brodin 2003). Finally in North Korea, port development is implemented through Chinese support due to prolonged political tensions between North and South (Ducruet and Jo 2008), while interKorean trade is 90 per cent maritime due to the war risk at the border of the Demilitarized Zone (DMZ) (Ducruet, Gelézeau and Roussin 2008).

This paper is more devoted to exploring the second research focus. The latter is based on the idea that firms are also influenced in their decision-making process by non-economic factors. This applies particularly to port selection by carriers. For instance, $\mathrm{Ng}$ (2006) suggests that port competition in North Europe is to a large extent explained by the subjective criteria of ocean carriers, besides economic factors such as handling cost and terminal efficiency. Investment locations of global terminal operators and vertically integrated shipping lines stem from a subtle combination of geographical, financial, cultural, and political factors (Airriess 2001; Olivier 2006; Jacobs and Hall 2007). The global network of maritime and port advanced producer services also reveals the persistence of historical patterns with a polarization on London (Jacobs, Ducruet and De Langen 2009). The world's main ocean carriers spread their port networks in a very distinct way on the globe, what reflects long-term historical and cultural influences of the firms (Frémont and Soppé 2004). While horizontal integration in the maritime sector tends to delete such influences, very few carriers have reached a truly global coverage: most of them remain geographically specialized within a given maritime region (Frémont and Soppé 2005), except for the special case of Maersk (Frémont 2007). One major contribution to this field is the one of Comtois and Wang (2003) on the shipping connections between China and Taiwan. Their analysis of the shipping networks of Coscon and Evergreen between 1990 and 2000 shows the importance of economic globalization, regional economic integration, hub-and-spoke development, and cooperation between carriers, resulting in diminishing discrepancies in the geographical spread of their ports of call in Asia and the world. Indeed, transport geography has surpassed political geography and geopolitics (Comtois and Wang 2003), as seen in the recent reopening of direct Taiwan-China vessel calls despite prolonged political tensions between the two parties after 46 years of blockade. Such examples indicate the political dimension of port and maritime developments.

The prime purpose of this paper is to examine the importance of the nationality of shipping companies in the evolution of their networks, especially under changing geopolitical backgrounds. Nationality is considered as an important factor because it expresses the territorial belonging of the firm. While shipping lines are said to operate in a borderless environment where economic priorities are dominant (Song 2003), we hypothesize that nationality will become paramount in certain geographical areas (space) and contexts (time), but not in others, resulting in different patterns among shipping companies serving the same markets. In order to verify such a hypothesis, the case of North Korea is worth analyzing because of responses to marked political shifts since 1990: Soviet influence, USSR collapse, isolation, trade embargo, economic decline, humanitarian support, economic reforms, foreign investments, economic cooperation, nuclear crisis, and 
changing relations with its main trading partners such as China, South Korea, Japan, and Russia. In addition, North Korea possesses eight international trading ports that are strategically located in Northeast Asia, one of the world's most dynamic maritime regions. However, one must not forget that the weight of maritime transport in North Korea remains limited due to:

- Preferential border trade with China: 80 per cent of North Korea's exports pass through Sinuiju and Dandong (China) in the northwest, while trade with Japan has constantly declined since 1998. Although inter-Korean trade occurs mostly on sea (90 per cent), it represents only 25 per cent of North Korea's international trade in 2005;

- Socialist development model: only 15-20 per cent of North Korea's international trade is supported by maritime transport (Ducruet and Jo 2008) while the rest occurs by road (18 per cent) and railway (74 per cent) despite domestic circulation problems and energy shortages since railways in this country are 70 per cent electrified (Tsuji 2005);

- Trade embargo and military control: ports are controlled by the army whose intention is not commercial but defense-oriented, giving a priority to land transport, and resulting in excessive shipping costs, port entry fees, and the necessity for foreign ships to obtain a special permit;

- Infrastructure limitations and lack of modern cargo handling facilities: liner shipping, passenger, and ro-ro constitute only 2 to 5 per cent of North Korea's port traffic on average (Ducruet, Roussin and Jo 2009). This is also reflected in the lack of container handling facilities while most cargo in North Korea is handled by hands at the docks using voluminous labor force, as a result of very little investment since the 1970s, except from Chinese support since 2005.

The paper is organized as follows. The first section introduces the data source on vessel movements and the methodology used for a geopolitical analysis of maritime connections, together with some general results. The second section focuses more on the impact of fleet nationality on the geographical pattern of North Korea's maritime connections. An analysis of those connections is proposed using cartography by fleet nationality, period, and port connected. The last section concludes about the implications of the paper for further research and policy.

\section{Analysing North Korea's maritime connections}

\subsection{Data source and methodology}

\section{Vessel movements calling at North Korean ports}

In this paper, we use Lloyd's Marine Intelligence Unit (LMIU) database on vessel movements. LMIU's database covers approximately 80 per cent of the world's merchant fleet and provides daily information on vessel movements for 120,000 vessels worldwide. It has the advantage of 
harmonizing the wide variety of schedules in a single database, notably for countries such as North Korea (and developing countries in general) for which bulk shipping and tramping are dominant. Sources such as Containerisation International or Drewry that are used by many scholars are not available due to the limited spread of containerization in North Korea. Indeed, most ports in this country are not well adapted for welcoming containerships in terms of cargo handling and terminal facilities: most cargoes are loaded and unloaded by hand using large labor force at the docks (Ducruet, Roussin and Jo 2009).

The information provided by LMIU comprises for every vessel its flag, capacity in deadweight tons (DWTs), ship operator, year of build, and type (e.g. tanker, general cargo, bulk, containership, etc.). Data have been extracted from the global database only for the vessels that called at North Korean ports between January 1985 and August 2006. It results in a database of 2,054 vessels operated by 1,069 companies. The period is justified by the necessity to compare differing geopolitical contexts so as to verify the impact of geopolitical change on maritime dynamics. We also know for every vessel the exact arrival and sailing date to and from each North Korean port.

Data on vessel movements has the advantage of being neutral (i.e. provided by an independent organization). This is critical when studying countries embedded in tense and unstable geopolitical contexts ${ }^{1}$. Also, it provides information that is not available from — and even ignored by - local institutions. The army manages ports in North Korea and is not willing to distribute any data about port traffic. In South Korea, the Ministry of Unification provides some data about inter-Korean shipping, but it excludes other shipments. Only broad estimations of overall North Korean maritime activity are provided in general reports and this is not enough detailed or accurate, although it requires substantial efforts for traffic forecasting based on different scenarios (Kim et al., 1998). Therefore, the LMIU database is the only source permitting a time series analysis of a country's maritime relations by port and by shipping line.

In order to analyze how diversely a country is connected to the outside world through shipping, we have restricted the study to the direct connections. It means that data is known only for the movement of ships between the previous and the next port of call within what maybe multiple port movements. For instance, we know that a vessel comes from Yokohama (Japan) before calling at Wonsan port in North Korea, and calls at Shanghai (China) afterwards. The rest of the voyage is ignored. While this lack of information about the total voyage may appear as a weakness, it has the advantage of allowing a clearer study about the role of neighboring countries in connecting North Korea to the rest of the world. Since North Korea's immediate neighbors (e.g. Japan, South Korea, China, and Russia) are also its main trade partners, there may be a good correspondence between vessel movements and trade relations. Direct relations also add a geographical value to the study, because they indicate how far the different ships have traveled for connecting North Korean ports.

The methodology used in this paper consists in comparing the evolution and geographical

\footnotetext{
${ }^{1}$ In our survey to shipping companies that called at North Korean ports during the last two decades, Maersk officials replied that North Korea "is one of the few places in the world we don't send our vessels". However, we can verify that Maersk Line has operated the Jolly Arancione, a containership of 30,217 DWT built in 1975 under Italian flag, from Panama Canal to the North Korean port of Nampo on January $15^{\text {th }} 2000$, and from Nampo to Incheon on March $17^{\text {th }}$. Unfortunately, our survey is not exploited in this paper due to the low response rate.
} 
distribution of vessels connecting North Korean ports. North Korean vessels are grouped as a specific category, while foreign vessels can be distinguished as another group or through several groups based on specific criteria. Our geopolitical approach uses fleet nationality, defined as the host country of a given vessel according to the location of the shipping companies' headquarters, rather than vessel flags, since the latter does not always refer to nationality because of flags of convenience. Therefore, we have redistributed the data of vessels according to the headquarter locations of vessel operators, notably by using online maritime directories ${ }^{2}$.

\section{Preliminary results}

One striking result is that North Korea has always been dependent on foreign ships for the largest part of its maritime traffic, which is between 50 per cent and 80 per cent on average (Figure 1). The crisis of the late 1980s that is related to the implosion of the USSR and the socialist block provoked a dramatic decline of foreign traffic, while North Korean capacities remained relatively stable. After 1991, with the collapse of the USSR, all capacities declined rapidly. A historical peak of activity for North Korean ships appeared in 1996-1997, which correspond to the empowerment of Kim Jong-Il in a context of food crisis. This may be explained by the use of naval ships for commercial purposes at a time of emergency. This effort disappears from 1998 while foreign ships regain their importance.

Thus, North Korea did not seek to keep a firm control on its traffic through its own fleet. Between 1999 and 2001, the peak of foreign activity at North Korean ports indicates the impact of humanitarian aid that was mostly shipped by sea. This peak can also be explained by shipments related to the $\mathrm{KEDO}^{3}$ project. It is only from 2002 that traffic volumes of foreign ships grow substantially, in a context of inter-Korean cooperation, economic reforms, and increased foreign investments. The building and operation of the Gaeseong Industrial Complex, located 60km from Seoul close to the Demilitarized Zone (DMZ) between North and South, best reflects the achievements of South Korea's cooperation efforts towards the North (Ducruet 2009). Especially, related shipments have an impact on foreign traffic from 2004, the start year of the operation of the industrial complex, and of the inter-Korean maritime agreement signed in 2004.

\footnotetext{
${ }^{2}$ See for instance the World Shipping Directory of Lloyd's Register \& Fairplay http://www.wsdonline.com.

${ }^{3}$ The Korean Peninsula Energy Development Organization (KEDO) is an international consortium created in 1994 for allowing North Korea's peaceful access to atomic energy. The construction of two 1,000 megawatts nuclear reactors that started in 1998 was supported by the two Koreas, the United States, Japan, the European Union and other nations. However, Washington withdrew itself from the consortium in 2002, accusing Pyongyang of doing illicit activities. The project was interrupted in November 2003 and cancelled in May 2006 despite a total cost of US $\$ 1.5$ billion.
} 


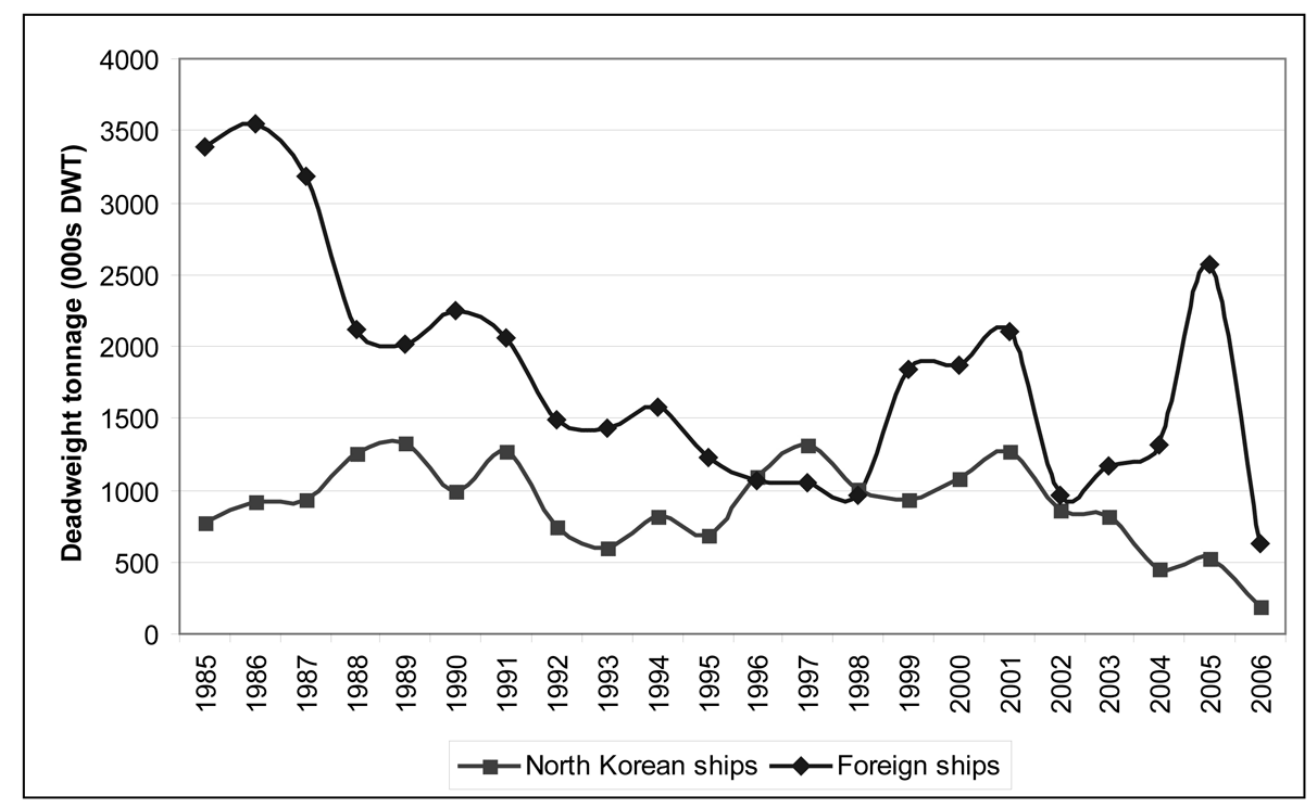

Source: realized by authors based on LMIU data

Figure 1. Cargo throughput at North Korean ports, 1985-2005

There are two possible ways to analyze the distribution of the different nationalities in depth: geographical and political. The geographical distribution (Figure 2) allows for distinguishing between (a) fleet having constant activity (North Korea, China, Japan, Hong Kong), (b) fleet that realized the majority of their activity before the fall of the USSR and the socialist block (Middle East, Europe, Africa, Southeast Asia, Russia), and (c) fleet that realized the majority of their activity in the recent period (South Korea, North America, Latin America). Following the peak of activity between 1999 and 2001 that is mostly due to humanitarian aid, only a few nationalities ensure North Korea's port activity: North Korea, South Korea, Japan, and China (i.e. North Korea's main trade partners). Since all these nationalities are located within Northeast Asia, they also highlight the loss of long-distance trades with other regions. Thus, the changing geography of fleet nationality closely echoes the changes in geopolitical and trade relations with the outside world. 


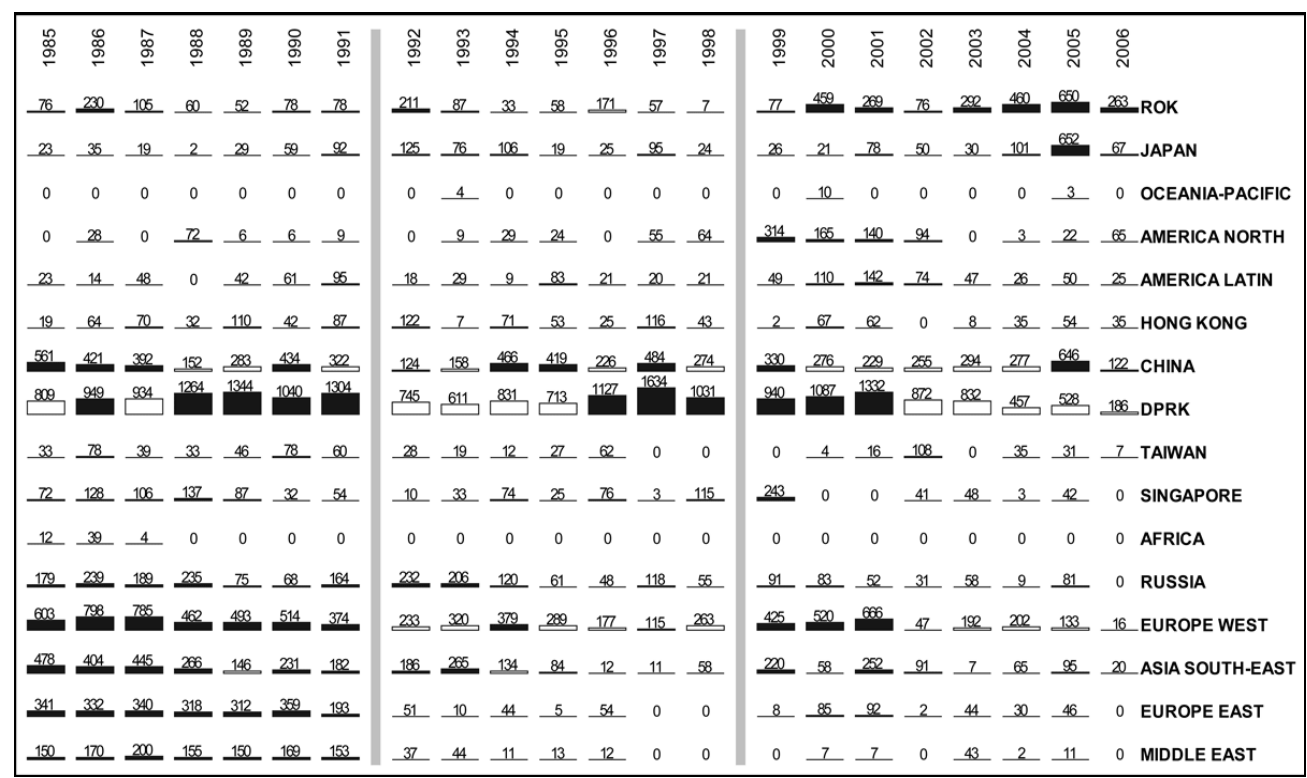

Source: realized by authors based on LMIU data

N.B. dark colors indicate values higher than row's average

Figure 2. Cargo throughput at North Korean ports by fleet nationality, 1985-2006 (Unit: 000s DWT)

The political distribution (Figure 3) is based on a conventional grouping of country nationalities into ideological families ${ }^{4}$. This distribution is considered relevant given the very specific ideological orientation of North Korea as one of the world's five remaining communist countries together with China, Cuba, Laos, and Vietnam. Although the content of such ideologies have changed dramatically over the study period, it can be hypothesized that some characteristics of former political systems remain pertinent even nowadays. Among foreign fleet, the socialistMarxist group that was the most important until the 1990s has faced the most dramatic decline afterwards. However, this trend is not specific to this group because all other fleets have also greatly declined according to a same pattern. Yet, important differences remain between the groups. For instance, the Western capitalist fleet (Europe and America) is clearly responsible for humanitarian support between 1999 and 2001, while the socialist-Marxist group keeps declining. Another deviation is the recent and unprecedented growth of the Asian capitalist fleet (South Korea, Hong Kong, Japan, Taiwan, and Singapore), mostly due to increased inter-Korean cooperation. Based on these inputs, the rest of the paper analyzes more detailed characteristics of both the North Korean and foreign fleets in terms of shipping and in-port performance. The simple distinction between two groups (North Korean and foreign) is kept for better clarity.

${ }^{4}$ The term socialist describes here all vessels belonging to countries that have been at one point of their history including elements of socialism in their constitution. 


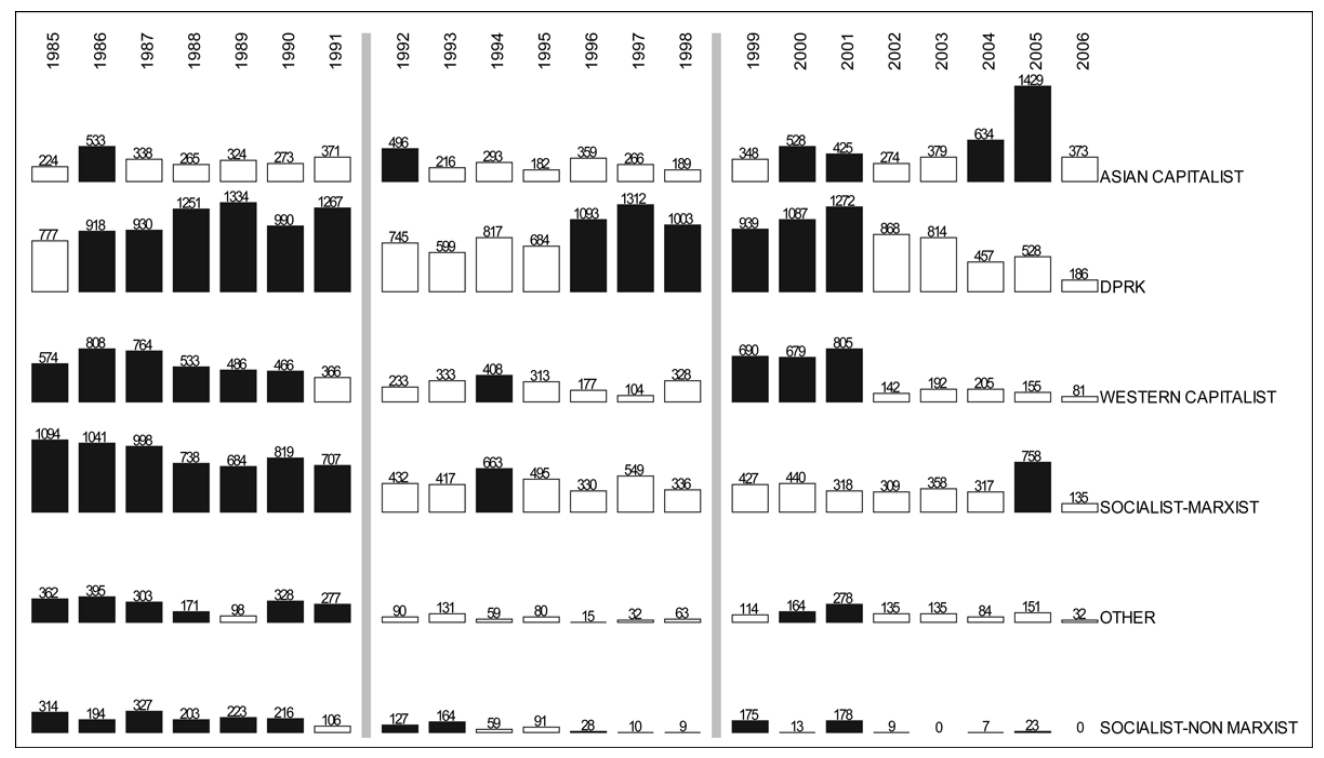

Source: realized by authors based on LMIU data

N.B. dark colors indicate values higher than row's average

Figure 3. Cargo throughput at North Korean ports by fleet political group, 1985-2006 (Unit: 000s DWT)

\subsection{Characteristics of North Korean port traffic by nationality}

\section{Cargo type}

Vessel traffic by main cargo type reveals interesting common trends and differences among the two groups. One common trend is the original dominance of general cargo vessels, at least until 1992. This highlights the specific role of shipping in this country. Land transport is dedicated to carry bulk products from heavy industries, agriculture and mining by road (18 per cent) and railway (74 per cent) (Tsuji 2005). Maritime transport specializes in the handling of semi-finished products that are not produced locally but are imported. Another comparable trend is the increase of traffic from the late 1990s to the early 2000s, at a time of geopolitical and profound economic crisis. However, one main difference is that North Korean vessels have been used extensively during the period of isolation and internal political crisis, at a time when North Korea could not rely too much on foreign vessels for ensuring its maritime connections (1994-1998), notably for basic commodities such general cargo and bulk. Finally, another interesting difference is the sudden disruption of foreign tanker shipping after 1987 (i.e. at a time when the USSR already started to collapse, and was not able to support North Korea's energy needs anymore). Finally, we clearly see that the increased shipping activity for all commodities from 2004 is dominantly the result of foreign fleet intervention, which confirms the increased dependence of North Korea upon foreign vessels. 


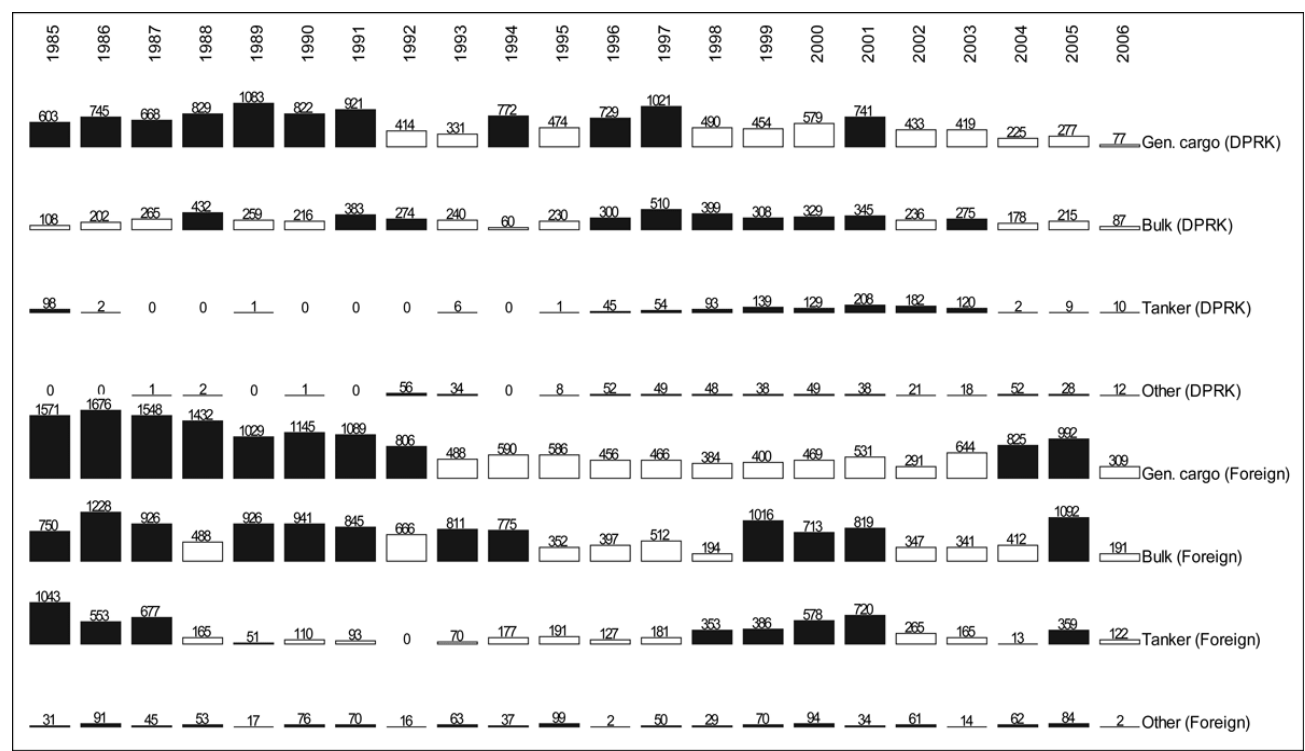

Source: realized by authors based on LMIU data

N.B. dark colors indicate values higher than row's average

Figure 4. Vessel types at North Korean ports, 1985-2006 (Unit: 000s DWT)

\section{Average vessel size}

The dominance of foreign ships is again reflected in Figure 5 with the average size of vessels calling at North Korean ports. One difference is structural since North Korean ships are always smaller than foreign ships. One common trend is the regular decrease of vessel sizes over time, except for specific peaks of oil shipments, and local projects such as Rajin-Seonbong Free-Trade Zone launched in 1991 at the border with Russia and China (Jo and Ducruet 2007). In the case of North Korean ships, larger ships that are more costly to repair and to operate tend to disappear over time. For foreign ships, two different reasons combine: the decreased trade volumes that necessitate fewer big ships, and the reduced port capacity and nautical accessibility in North Korea due to the lack of investment in port facilities. Thus, average vessel size is a good indicator of port performance that helps differentiating the different fleets.

In addition, vessel traffic also reflects the geopolitical evolution of the peninsula. The crisis with Japan in 1998 due to North Korean missile tests marks the lowest vessel size for foreign ships. In 1999, Washington levies some sanctions against North Korea. The sudden decline in 2002 marks the ceasing of oil shipments from United States, Japan, and European Union due to suspected uranium enrichment activities of North Korea. The new increase in 2005 may reflect the impact of the inter-Korean agreement that liberalizes Korean vessels' movements between North and South. The dramatic fall in 2006 is inevitably influenced by the missile tests in July; it is only from February 2007 that the situation has reached peaceful grounds. 


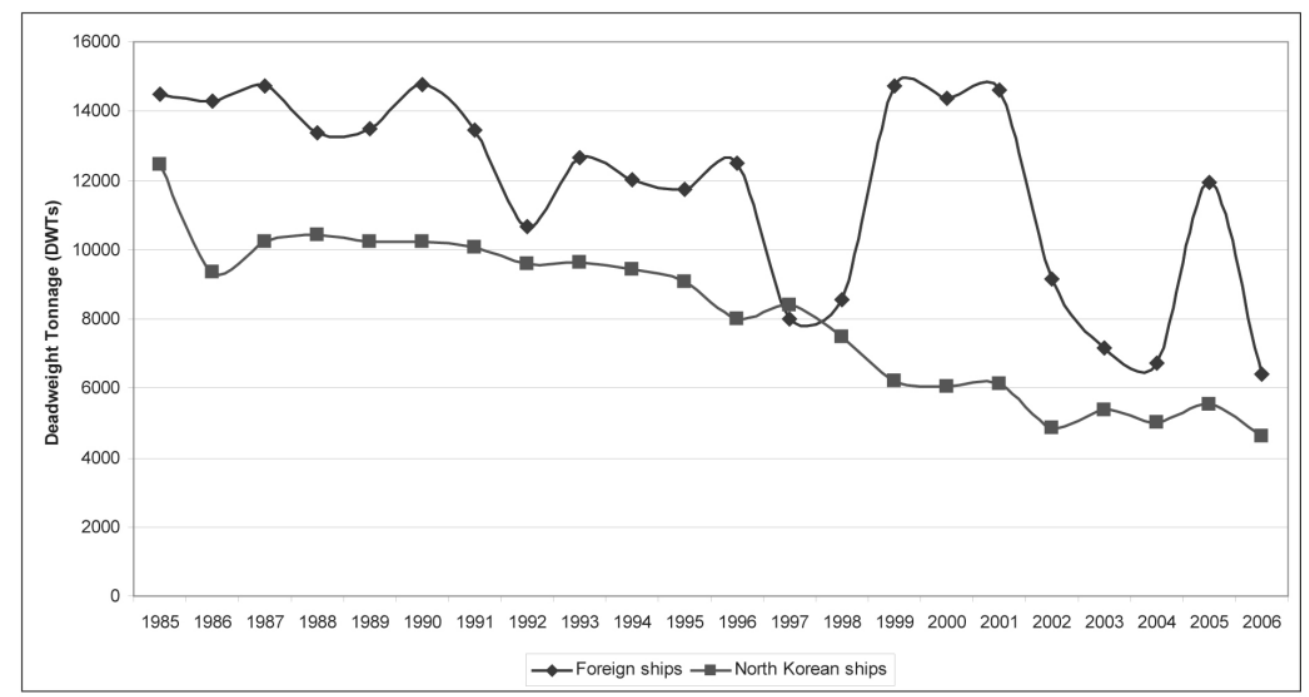

Source: realized by authors based on LMIU data

Figure 5. Average vessel size at North Korean ports, 1985-2006

\section{Average vessel age}

As showed in Figure 6, North Korean ships were younger than foreign ships before 1991. After this date, both fleets follow a similar trend but from 1997 North Korean vessels tend to age more rapidly than other vessels. Although foreign ships also age gradually, their average age oscillates between 15 and 17 years, while North Korean vessels reach the age of 23 to 25 years on an average basis. This implies important gaps with the average vessel age in developing countries, which was approximately 14 years in 2000 (UNCTAD 2000). As shown in Appendix 1, the dynamic of North Korean shipbuilding has slowed since the mid-1980s: most ships have been constructed before 1984. From 1997, the relative stability of average vessel age for North Korean ships can be attributed to the necessity for North Korea to keep using its same old ships regardless of their technical difficulties during the crisis consuming the country. Among all the reasons invoked by Japanese authorities for banning North Korean ships from their ports were the technical deficiencies and the lack of hygiene onboard (Lloyd's Register 2004). In order to sustain its maritime trade without investing in its fleet, North Korea has pushed the limits of its vessels beyond tolerance. This important technical factor may explain for a large part the striking importance of foreign vessels in total North Korean maritime activity (cf. Figure 1), because the country is not able to handle the majority of its seaborne cargo flows by itself. The slight decrease in 2006 may correspond to the arrival of new vessels in the North Korean fleet, either through refurbishment, renovation, or shipbuilding, but there is great difficulty verifying such facts. 


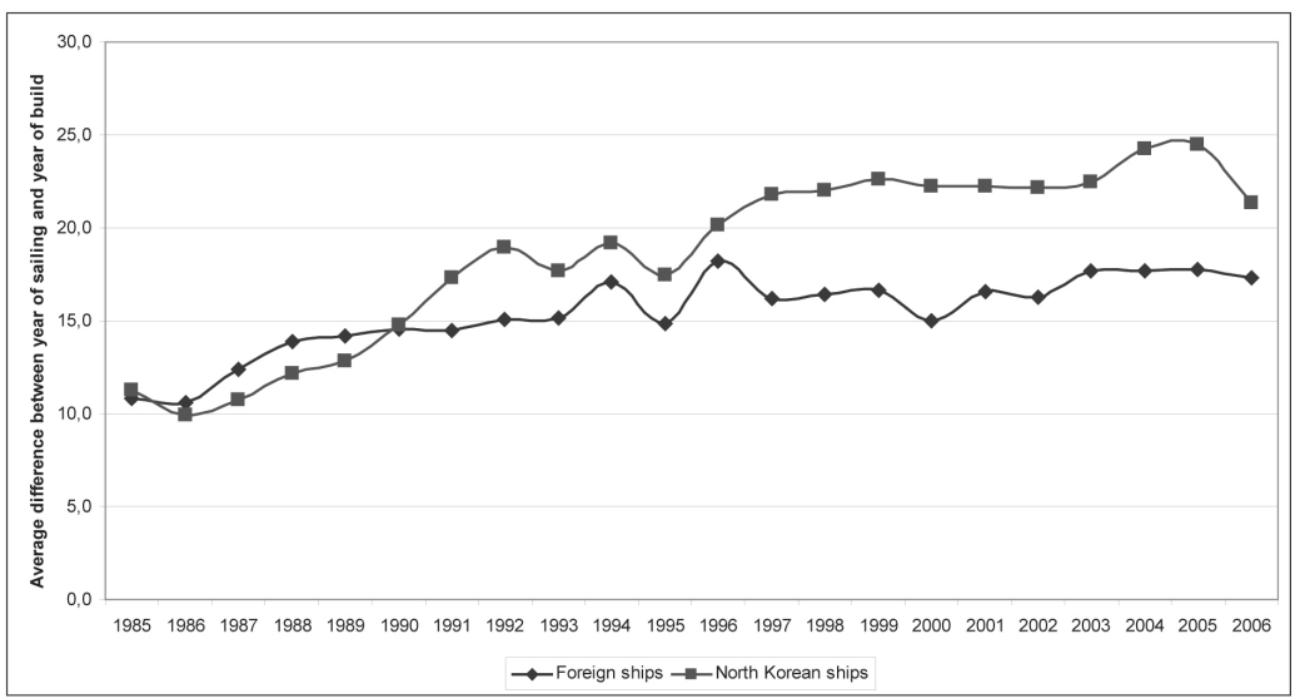

Source: realized by authors based on LMIU data

Figure 6. Average vessel age at North Korean ports, 1985-2006

\section{Average berthing time}

The calculation of the average berthing time (Figure 7) excludes a few vessels that spent more than one year at a North Korean port. Results show the longer berthing time of North Korean ships compared to foreign ships. This is easily explained by the fact North Korean ships anchor "at home" and may stay longer on an average basis than other ships. From the late 1990s, however, the gap between the two fleets' average berthing time gets wider. While it slightly decreases for foreign ships, it dramatically increases for North Korean ships, at least until the early 2000s, when the two trends get closer.

The enormous gap of 20 to 30 days on average stems from the geopolitical isolation of North Korea. The reduction and disappearance of former trade routes deprived North Korean ships from their activity, which is worsened by the lack of fuel supplies. Thus, a majority of them remained anchored at their home terminals, until the situation improved from 2000 onwards. Still in 2001, important delays at North Korean ports are reported in the specialized press (Lloyd's Register 2000 and 2001). The peak of 2005 marks North Korea's very unstable attitude about humanitarian associations and nuclear talks with other nations.

In the case of foreign ships, the regular decrease of average berthing time also indicates increased flexibility of North Korean ports' management. Military control over North Korean ports may have favored more rapid turnaround shifts of foreign ships through less cumbersome regulations. This illustrates the shift from political to economic priorities given the country's difficulties and the effect of port modernization implemented through Chinese support in the ports of Nampo and Rajin. At Nampo, new container berth and general cargo quays are reported since 
2005 while there are ongoing efforts to upgrade road access and container equipments at Rajin since 1996 (Jo and Ducruet 2006). However, it may be the case that the decreasing size of vessels calling at North Korean ports also influences the results, since less time is required for handling cargoes to and from smaller vessels.

The distinction between North Korean fleet and other foreign fleets allows understanding the contrasting trends that North Korea has faced in the last two decades. There are also common trends that relate to the internal situation of ports in the country and to the wider geopolitical context.

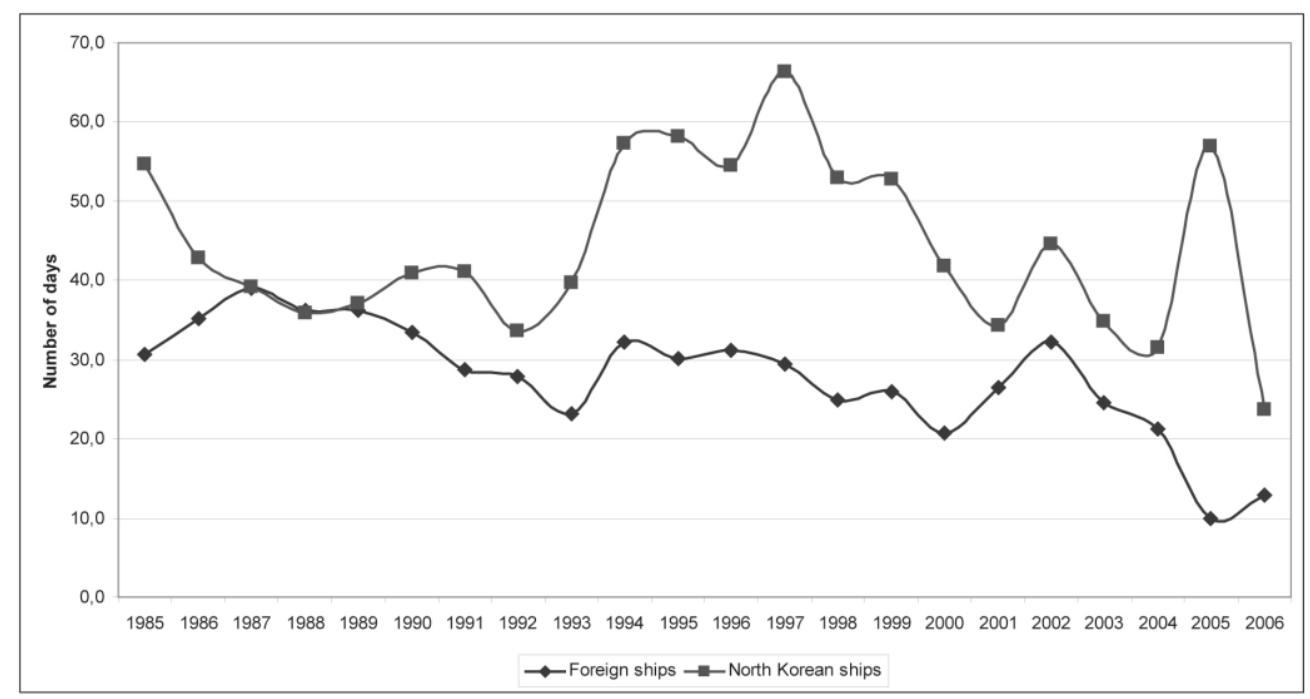

Source: realized by authors based on LMIU data

Figure 7. Average berthing time at North Korean ports, 1985-2006

\section{A geographical perspective on maritime connections}

\subsection{The differentiation of shipping networks by fleet nationalities}

In Figure 8, we compare the distribution of North Korea's direct maritime connections within East Asia distinguishing between North Korean fleet and foreign fleets. The two patterns have several similarities and differences. In terms of similarities, there is a reduction of the connections with Singapore and Hong Kong. The main role of those two global pivotal hubs is to ensure maritime trade connection between East Asia and the other economic poles of the northern hemisphere, Europe and North America. Therefore, the decline of their connectedness with North Korea indicates the retreat of North Korea from the world economy. Instead, we see the growing importance of Taiwan as a transit platform with the rest of the world. Perhaps, this shift comes 
from the more neutral role of Taiwan in a context of diplomatic tension. Thus, ships calling at North Korean ports may have preferred using Taiwanese ports as transit ports instead of more "politicized" ports such as Singapore, Hong Kong, and other Chinese ports. Yet, Singapore maintains more connections with foreign ships than with North Korean ships in the third period. Finally, we see an increase of connections to Russian Far-East ports (e.g. Nakhodka, Vladivostok, Vostochnyy, Posyet, and Zarubino $)^{5}$.

In terms of differences, we see great contrasts in the role of neighboring countries in connecting North Korea with the outside world. Even in Taiwan, the ports where North Korean or foreign ships call are different: Kaohsiung is the hub for foreign ships, while North Korean ships are dominant in Taichung, Keelung, and Hualien. For other countries, their role can be differentiated as follows:

- There is a dramatic decline of Chinese and Japanese connections for foreign ships, while those connections are increasing for North Korean ships;

- Foreign ships are increasingly concentrated at South Korean ports, while those ports are totally avoided by North Korean ships;

- Foreign ships tend to concentrate along a Singapore-Taiwan-Busan axis that is reflecting economical factors (least deviation from the main routes), while North Korean ships maintain close connections with neighboring Chinese and Japanese ports (short-distance calls);

- North Korean ships show more dispersed connections over time while foreign ships show more concentrated connections. This is partly a consequence of the ageing and deficiencies of North Korean ships: the impossibility realizing economies of scale.

The respective hubs of North Korean and foreign ships are thus very different. The circulation pattern of North Korean ships shows some permanency in the importance of Yellow Sea Chinese ports such as Dalian, Qinhuangdao, Tianjin, Lianyungang, and Qingdao. In Japan, North Korean ships concentrate at Niigata due to the regular ferry link with the North Korean port of Wonsan, but this connection has greatly reduced due to the banning of North Korean ships from Japanese ports since 1998. In the third period, Niigata traffic was shifted to Nagoya, Maizuru, Kisarazu, Tobata, and Oita. The bulk of North Korea's transit trade increasingly uses Incheon and other South Korean ports as main pivots in recent years ${ }^{6}$.

\footnotetext{
${ }^{5}$ There are ongoing prospects on developing further Rajin-Seonbong FTZ through Russian support, by connecting the zone to Siberian oil and gas fields by pipeline in exchange of electricity, or to develop a transport corridor towards Russia for distribution (Cargonews Asia 2007) while China is securing Rajin's container terminals through 50-years concessions and building of industrial complex (Choe 2007).

${ }^{6}$ According to Ducruet (2008), containers destined to and coming from North Korean ports have progressively concentrated at Incheon (more than 50 per cent TEUs since 2003 and more than 25 per cent DWTs since 2004 onwards) and South Korean ports in general (more than 50 per cent DWTs and more than 80 per cent TEUs since 2004 onwards). He interprets this phenomenon as a combination between three factors: local factor (infrastructure limitations and trade growth in North Korea), regional factor (inter-Korean maritime agreement and economic cooperation), and global factor (concentration of shipping services at centrally located and well-equipped ports).
} 

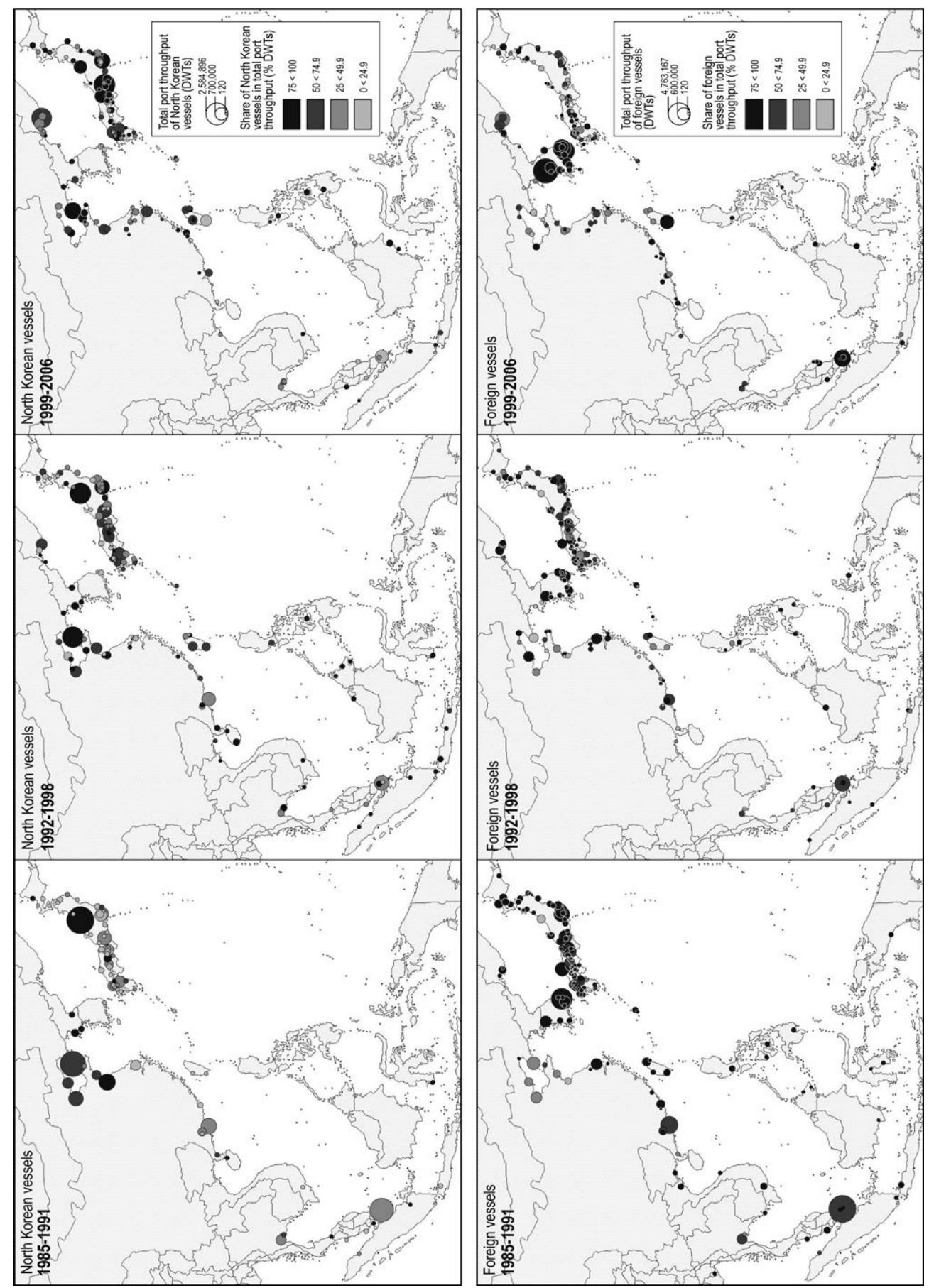

Source: realized by authors based on LMIU data

Figure 8. Distribution of North Korea's direct maritime connections by fleet, port and period 


\subsection{Hub concentration by fleet nationality}

Different fleet nationalities are selected in Figure 9 as a means of highlighting the influence of political factors on shipping networks. One first general trend is that most fleets follow the changing trading routes, with the increase of South Korean connections, and the decrease of Japanese connections, except for the North Korean fleet. Between 2001 and 2005, the share of North Korea's international trade with South Korea has increased from 15 per cent to 26 per cent while the share with Japan has decreased from 18 per cent to 5 per cent. Thus, it is normal that the share of South Korean ports in most fleets has increased accordingly, from 8 per cent in the first period to 31 per cent in the third period on average (see Figure 9 for percentages). Especially, the Japanese fleet has shifted from dominant North Korea/Japan connections (81 per cent to 12 per cent) to dominant North Korea/South Korea connections (3 per cent to 60 per cent). Conversely, South Korean ships that were connecting directly Japan and North Korea (47 per cent to 6 per cent) have been redirected between North and South (19 per cent to 57 per cent). Chinese ships as well have converged to the South Korean hub (6 per cent to 52 per cent), leaving Japanese connections behind (37 per cent to 20 per cent).

Some fleets do not follow the shift to South Korean ports. Due to political obstacles with South Korea, North Korean ships were forced to keep almost unchanged their traditional connections with Japan ( 42 per cent to 49 per cent) and China (33 per cent to 21 per cent). The share of Japan is quite surprising given the banning of North Korean ships from Japanese ports. As in Figure 9, South Korean ports are simply avoided by North Korean ships: they contribute only 1 per cent of their connections in the third period, following the inter-Korean maritime agreement of 2004. The loss of connections with Chinese ports was shifted to Russian ports ( 0 per cent to 14 per cent), in a context of increased cooperation across the Tumen River Delta. Another counterexample is the Russian fleet: although it has also shifted to South Korean ports (1 per cent to 13 per cent) and from Japanese ports (49 per cent to 7 per cent), the main trend is the concentration of traffic upon Russian ports (8 per cent to 70 per cent). This example confirms the regional preference of fleet nationalities: Russian ports are more connected by Russian ships than by other ships, and the same applies to Chinese, South Korean, Japanese, and other ports. 


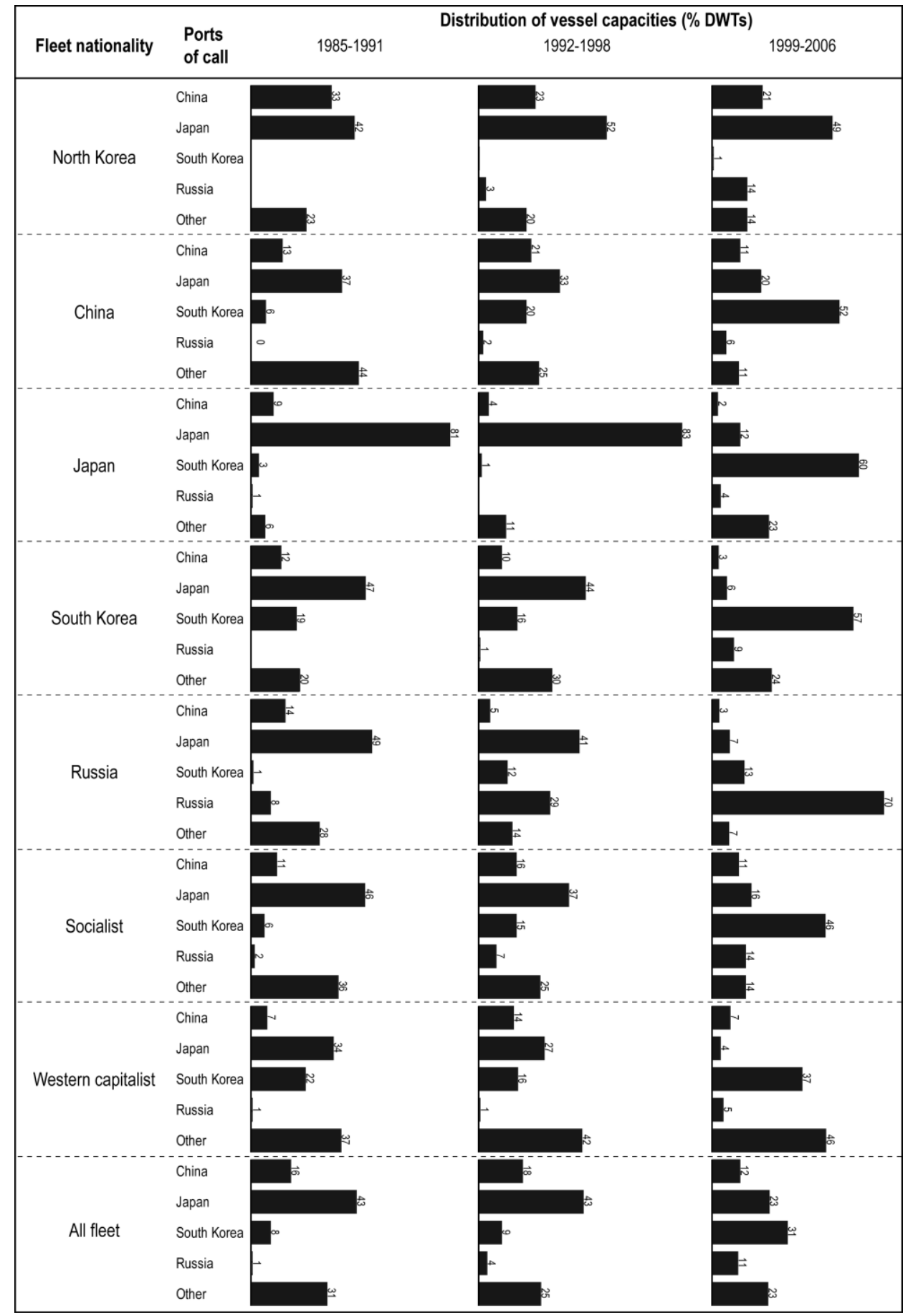

Source: realized by authors based on LMIU data

Figure 9. Distribution of vessel traffic by fleet nationality and direct connection, 1985-2006 
Finally, the various weights of "other ports" (i.e. all ports located outside Northeast Asia) are a good indicator for differentiating the fleets. For instance, some fleets are more regional (circulation within Northeast Asia) while others are more international (connecting North Korea to other regions). North Korean and socialist - of which Chinese and Russian - fleets have become more regional over time (i.e. the share of other ports has dropped dramatically: 36 per cent to 14 per cent for socialist ships, 28 per cent to 7 per cent for Russian ships, 44 per cent to 11 per cent for Chinese ships, 23 per cent to 14 per cent for North Korean ships). Other fleets domiciled in capitalist countries show a net increase of the share of other ports: 37 per cent to 46 per cent for Western ships (North America, Western Europe, and Oceania), 20 per cent to 24 per cent for South Korean ships, 6 per cent to 23 per cent for Japanese ships. Therefore, political considerations not only matter but also have a strong influence on the way ports are connected with each other.

\section{Conclusion}

This paper has confirmed the importance of nationality in the nature and evolution of shipping networks. It reveals the strong dependence of North Korea's port activity on foreign vessels. The North Korean fleet and ports encounter increasing technical difficulties, as seen in the evolution of vessel size, age, berthing time, and geographical reach. Indeed, the North Korean fleet has confined most of its activity to intra-Northeast Asia, while foreign fleets maintain extra-Northeast Asia connections. Finally, this paper explores North Korea's reputation, as the most closed country is the world, in the light of the proportion of foreign ships calling at its ports.

The interplay between geo-political change and ship operators' nationalities raises key issues. On the one hand, the activity of foreign vessels at North Korean ports has been strongly affected by the difficulties of North Korea (e.g. loss of socialist trades, diplomatic tensions, internal crisis), while the traffic realized by the North Korean fleet remains relatively stable over time. It means that the evolution of foreign fleet traffic is a good indicator of the evolution of North Korea as a whole. Accordingly, recent traffic growth confirms the positive impact of inter-Korean economic cooperation and increased foreign investment. On the other hand, the results highlight important changes in the operation of shipping in general. Recent traffic shift to South Korean ports ensuring the majority of North Korea's transit trade shows the growing importance of market forces compared to political factors. Regardless of their nationality, shipping companies seek to reduce their costs through economies of scale and technological efficiency. Except for the North Korean fleet, all others select South Korean ports as their main connection with North Korea. North Korean and foreign fleets have evolved from geographical overlap to geographical specialization: North Korean vessels concentrate at the neighboring Chinese, Russian, and Japanese ports (short distance calls), while foreign vessels concentrate at South Korean ports and other inter-regional pivots such as Taiwan and Singapore (long-distance calls). Thus, we clearly see that for North Korean vessels, the political factor remains fundamental, but for foreign fleet, the economic factor has taken increasing significance in the design of their regional port network. One exception is the Russian fleet that concentrates dominantly on the Russia-North Korea link in the recent period. 
Overall, the research provides a simple methodology that can be applied to other developing and constrained economies for which accessing port-related statistics is a real challenge and, in some cases such as North Korea, rather impossible. Referring to the work of Comtois and Wang (2003) on the Taiwan Strait, there is a confirmation that globalization and regionalization processes tend to diminish the importance of geopolitical and political factors, due to the economic imperatives of shipping lines in terms of port selection. Whether the new transport geography of North Korea's maritime connections will affect its own geopolitical representation of the world and its political behavior remains to be seen.

\section{Acknowledgments}

The authors would like to thank Dr. Lee Sung-Woo (Korea Maritime Institute, Seoul) for his useful comments. Thanks also go to the three anonymous reviewers whose comments helped improving an earlier version of this paper and to Editor Mr. Ha Hun-Koo for his kind support.

\section{References}

Airriess, C.A. 2001. The regionalization of Hutchinson Port Holdings in Mainland China. Journal of Transport Geography 9(4): 267-278.

Basu, D.K. (ed) 1985. The rise and growth of the colonial port cities in Asia. Santa Cruz CA: Center for South Pacific Studies.

Brodin, A. 2003. Baltic ports and Russian foreign trade: studies in the economic and political geography of transition. Gothenburg: Univ. of Gothenburg.

Broeze, F. (ed) 1989. Brides of the sea: Port cities of Asia from the $16^{\text {th }}-20^{\text {th }}$ centuries. Honolulu: University of Hawaii Press.

Cargonews Asia. 2007. Russia, China vie for control of North Korean port. March 6.

Carluer, F., Alix, Y., Joly, O. 2008. Global logistic chain security: Economicimpacts of the US $100 \%$ container scanning law. Le Havre: EMS.

Choe, S.H. 2007. Oil is shipped to North Korea under nuclear shutdown pact. New York Times, July 13.

Comtois, C. 1994. The evolution of containerization in East Asia. Maritime Policy and Management 21(3): 195-205.

Comtois, C. 1999. The integration of China's port system into global container shipping. Geojournal 48(1): 35-42.

Comtois, C., Wang, J.J. 2003. Géopolitique et transport : nouvelles perspectives stratégiques dans le détroit de Taiwan. Études Internationales 34(2): 213-226.

Ducruet, C. 2008. Hub dependence in constrained economies: the case of North Korea. Maritime 
Policy and Management 35(4): 377-394.

Ducruet, C. 2009. Free-trade zones in the Koreas. In: Bost, F. (ed) World Atlas of Free-Trade Zones. Paris: La Documentation Française (in French, in press).

Ducruet, C., Gelézeau, V., Roussin, S. 2008. Les connections maritimes de la Corée du Nord : recompositions territoriales dans la péninsule coréenne et dynamiques régionales en Asie du Nord-Est. L'Espace Géographique 37(3): 208-224.

Ducruet, C., Jo, J.C. 2008. Coastal cities, port activities and logistic constraints in a socialist developing country: the case of North Korea. Transport Reviews 28(1): 1-25.

Ducruet, C., Notteboom, T.E. and Langen de, P.W. 2009. Revisiting inter-port relationships under the New Economic Geography research framework, in: Notteboom, T.E., Ducruet, C., Langen de, P.W. (eds) Ports in Proximity: Competition and Coordination among Adjacent Seaports, Aldershot, Ashgate (in press).

Ducruet, C., Roussin, S. 2008. Inter-Korean maritime dynamics in the Northeast Asian context: peninsular integration or North Korea's pragmatism? Paper presented at the International Workshop on North / South Interfaces in the Korean Peninsula, EHESS, Paris, December 17-19.

Ducruet, C., Roussin, S. and Jo, J.C. 2009. Going West? Spatial polarization of the North Korean port system. Journal of Transport Geography (in press).

Ducruet, C., Van Der Horst, M. R. 2009. Transport integration at European ports: measuring the role and position of intermediaries. European Journal of Transport and Infrastructure Research 9(2): 121-142.

Frémont, A. 2007. Global maritime networks: the case of Maersk. Journal of Transport Geography 15(6): 431-442.

Frémont, A., Soppé, M. 2004. Les stratégies des armateurs de lignes régulières en matière de dessertes maritimes. Belgéo 4: 391-406.

Frémont, A., Soppé, M. 2005. Transport maritime conteneurisé et mondialisation. Les Annales de Géographie 642: 187-200.

Jacobs, W. 2007. Port competition between Los Angeles and Long Beach: an institutional analysis. Tijdschrift voor Economische en Sociale Geografie 98(3): 360-372.

Jacobs, W., Ducruet, C. and De Langen, P.W. 2009. Integrating world cities into production networks: the case of port cities. GaWC Research Bulletin 298, http://www.lboro. ac.uk/gawc/rb/rb298.html

Jacobs, W., Hall, P.V. 2007. What conditions supply chain strategies for ports? The case of Dubai. Geojournal 68(4): 327-342.

Jo, J.C., Ducruet, C., 2006. Maritime trade and port evolution in a socialist developing country: Nampo, gateway of North Korea. The Korea Spatial Planning Review 51, 3-24.

Jo, J.C., Ducruet, C. 2007. Rajin-Seonbong, new gateway of Northeast Asia. Annals of Regional Science 41(4): 927-950.

Kim, H.S., Lee, S.W. and Yoo, J.M. 1998. The directions of the port development policy in the unified Korea. Seoul: Korea Maritime Institute.

Kunth, A., Thorez, P. 2005. Frontières et transport, frontières de transport: continuités, mutations et transition entre l'Ouest et l'Est de l'Europe. Revue d'Etudes Comparatives Est-Ouest 
36(3): 11-42.

Lee, S.W., Ducruet, C. 2009. Spatial glocalization in Asia-Pacific hub port cities: a comparison of Hong Kong and Singapore. Urban Geography 30(2): 162-184.

Lloyd's Register. 2000. North Korea bans neighbor's boxes. December $7^{\text {th }}$.

Lloyd's Register. 2001. Delays in North Korean port. June $1^{\text {st }}$.

Lloyd's Register. 2004. Japan will ban North Korean ships. June $2^{\text {nd }}$.

$\mathrm{Ng}$, K.Y.A. 2006. Assessing the attractiveness of ports in the North European container transshipment market: an agenda for future research in port competition. Maritime Economics and Logistics 8(3): 234-250.

Ng, K.Y.A., Pallis, A.A. 2007. Political culture and port governance. Paper presented at the International Congress on Ports in Proximity. Antwerp/Willemstad/Rotterdam, 5-7 December.

Notteboom, T.E. 2006. Container throughput dynamics in the East Asian container port system. Journal of International Logistics and Trade 4(1): 31-52.

Olivier, D. 2006. The globalization of port business: An Asian perspective. Unpublished $\mathrm{PhD}$ dissertation, University of Hong Kong.

Papon, P. 1996. Le sixième continent: Géopolitique des océans. Paris: Odile Jacob.

Parola, F., Lee, S.W. and Ferrari, C. 2006. On the integration of logistics activities by shipping lines: the case of East Asia. Journal of International Logistics and Trade 4(1): 109-129.

Rimmer, P.J. 2004. Global flows, local hubs, platforms, corridors and regional economic integration in Northeast Asia. Journal of International Logistics and Trade 1(2): 1-18.

Rimmer, P.J., Comtois, C. 2005. China's extra and intra-Asian liner shipping connections 19902000. Journal of International Logistics and Trade 3(1): 75-97.

Robinson, R. 1998. Asian hub/feeder nets: the dynamics of restructuring. Maritime Policy and Management 25(1): 21-40.

Rowlinson, M. and Wixey, S. 2002. The politics and economics of developing coastal shipping. Paper presented at the International Conference of the International Association of Maritime Economists. Panama City, Republic of Panama, November 12-15.

Slack, B. 1993. Pawns in the game: ports in a global transportation system. Growth and Change 24(4): 379-388.

Song, D.W. 2003. Port co-opetition in concept and practice. Maritime Policy and Management 30(1): 29-44.

Thorez, P. 1998. La difficile mutation des transports maritimes dans la CEI. Bulletin de l'Association des Géographes Français 1:343-362.

Tsuji, H. 2005. The transport infrastructure of the DPRK. Niigata: Economic Research Institute for Northeast Asia.

UNCTAD, 2000. World seaborne trade continues growth in 1999. http://www.unctad.org (Accessed December 2008).

Vigarié, A. 1995. La mer et la géostratégie des nations. Paris: Economica \& Institut de Stratégie Comparée.

Yap, W.Y., Lam, J.S.L. and Notteboom, T.E. 2006. Developments in container port competition in East Asia. Transport Reviews 26(2): 167-188. 
Appendix: Some characteristics of the North Korean fleet (Source: LMIU)

Evolution of shipbuilding in North Korea, 1961-2004

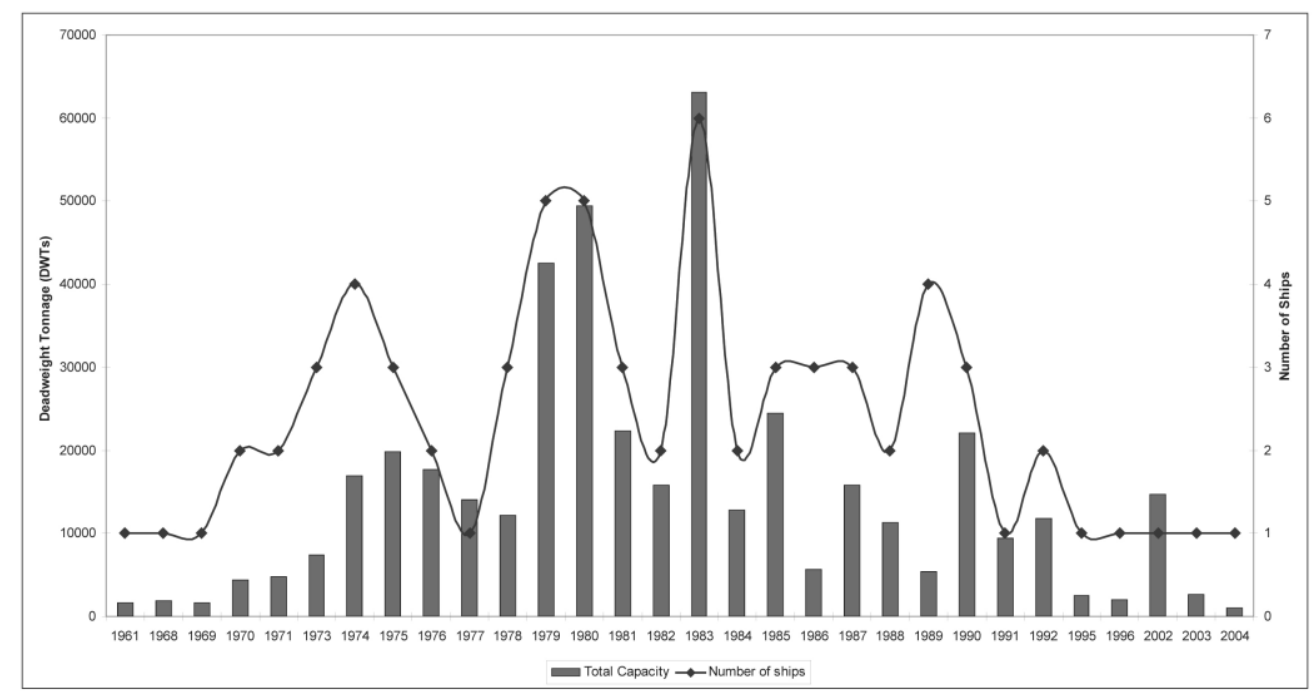

Distribution of vessel types

\begin{tabular}{c|c|c}
\hline Vessel type & DWT & No. \\
\hline \hline Bulk & 366,422 & 17 \\
Containers & 18,002 & 2 \\
Fishing & 3,441 & 6 \\
General cargo & $1,075,748$ & 152 \\
Other & 502 & 1 \\
Passenger & 2,014 & 1 \\
Research & 1,950 & 1 \\
Tanker & 129,052 & 17 \\
\hline Total & $1,597,131$ & 197 \\
\hline
\end{tabular}


Fleet capacity by main operators

\begin{tabular}{c|c|c}
\hline Vessel operator & DWT & No. vessels \\
\hline \hline Korea G. & 408,285 & 48 \\
Ocean Maritime M. & 204,206 & 15 \\
Taedonggang & 118,419 & 9 \\
Tonghae S.C. & 71,660 & 8 \\
Korea T. & 49,466 & 3 \\
Manpok & 45,889 & 3 \\
\hline Opera Marine & 40,999 & 1 \\
Korea Daehung & 22,706 & 1 \\
Korea J. & 20,346 & 2 \\
Korea Tonghae & 18,081 & 2 \\
\hline Total (173 operators) & $1,597,131$ & 197 \\
\hline
\end{tabular}

North Korean vessels still operated in 2006

\begin{tabular}{|c|c|c|c|c|}
\hline Vessel name & Year of build & GRT & DWT & Cargo type \\
\hline Mi Rae & 1978 & 17,656 & 28,973 & Bulk \\
\hline Mang Yong Bong 92 & 1992 & 9,672 & 2,014 & Passenger \\
\hline Chol San Bong Chong & & & & \\
\hline Nyon Ho & 1986 & 6,689 & 5,483 & Gen. cargo \\
\hline Bu Hung & 1977 & 5,386 & 7,720 & Gen. cargo \\
\hline Xoh Paek & 1974 & 3,597 & 6,066 & Gen. cargo \\
\hline Hwang Gum San & 1975 & 2,920 & 4,136 & Gen. cargo \\
\hline Bong Hoa San & 1970 & 2,897 & N/A & Gen. cargo \\
\hline Tu Ru Bong & 1990 & 2,716 & 2,978 & Gen. cargo \\
\hline Un San & 2003 & 2,044 & N/A & Gen. cargo \\
\hline Rimsugoon & 1970 & 2,010 & 3,407 & Gen. cargo \\
\hline Song Hoa 2 & 1989 & 1,584 & 2,110 & Gen. cargo \\
\hline Song Hoa 5 & 2001 & 1,583 & N/A & Containers \\
\hline Jisong-5 & 1993 & 1,580 & 2,232 & Gen. cargo \\
\hline Jisong-3 & 1981 & 1,548 & 1,978 & Gen. cargo \\
\hline Zo Kwang & 1981 & 1,265 & 1,600 & Gen. cargo \\
\hline Pong Yue & 1991 & 1,221 & N/A & Gen. cargo \\
\hline So Hung 1 & 1980 & 1,212 & 1,580 & Gen. cargo \\
\hline Dae Hung 6 & 1984 & 1,038 & 1,665 & Tanker \\
\hline Kum Un San & 1988 & 1,023 & 2,070 & Tanker \\
\hline Ji Song 7 & 1984 & 1,018 & 1,171 & Gen. cargo \\
\hline Daesong 422 & 1982 & 946 & 899 & Gen. cargo \\
\hline Bu Yon & 1986 & 699 & 2,100 & Tanker \\
\hline Dae Hung 12 & 1986 & 498 & 1,180 & Tanker \\
\hline
\end{tabular}

N.B. GRT refers to Gross Registered Tons 
